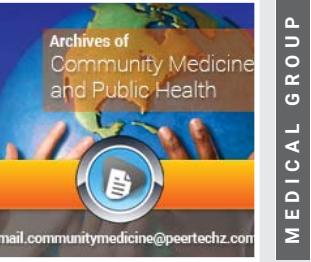

\title{
Crossing intersectoral boundaries to reach out to vulnerable populations with chronic conditions in five European regions
}

Arturo Alvarez Rosete ${ }^{1}$, Marta M Pisano-González ${ }^{2 *}$, An LD Boone ${ }^{3}$, Raquel Vazquez-Alvarez ${ }^{4}$, Delia PeñacobaMaestre ${ }^{4}$, Verushka Valsecchi ${ }^{5}$, Yves-Marie Pers ${ }^{6}$, Sabrina Zora7, Alberto Pilotto7, Siok-Swan Tan ${ }^{8}$, Hein Raat ${ }^{8}$, Graham Baker $^{9}$ and Sergio Vallés García ${ }^{10}$

${ }^{1}$ Independent Researcher and Consultant, C/ Fernando de Rojas 3, Castellanos de Moriscos, Salamanca, Spain

${ }^{2}$ Ministry of Health of the Principality of Asturias (CSPA), C/ Ciriaco Miguel Vigil, 9, 33006 Oviedo Asturias, Spain

${ }^{3}$ Public Health General Directorate, Ministry of Health of the Principality of Asturias (CSPA), C/ Ciriaco Miguel Vigil, 9, 33006 Oviedo - Asturias, Spain

${ }^{4}$ Health Service of the Principality of Asturias (SESPA), Oviedo, C/ Ciriaco Miguel Vigil, 9, 33006 Oviedo - Asturias, Spain

5IRMB, University of Montpellier, INSERM, CHU Montpellier, Montpellier, France

${ }^{6}$ Clinical Immunology and Osteoarticular Diseases Therapeutic Unit, Lapeyronie University Hospital, Department of Rheumatology, Lapeyronie Montpellier (CHUM), 371, Avenue du Doyen Gaston Giraud, 34295 Montpellier Cedex 5, France

${ }^{7}$ Department of Geriatric Care, Orthogeriatrics and Rehabilitation, E.O. Galliera Hospital (EOG), Mura delle Cappuccine 14, 16128 Genoa, Italy

${ }^{8}$ Department of Public Health, Erasmus University Medical Center (EMC), P.O. Box 2040, 3000 CA Rotterdam, Netherlands

${ }^{9}$ Quality Institute for Self Management Education \& Training (QISMET), Harbour Court, Compass Road, North Harbour, Portsmouth, Hampshire, P06 4ST, United Kingdom

${ }^{10}$ General Director of of Care, Humanization and Social Health Care at the Regional Ministry of Health of the Principality of Asturias (CSPA), C/ Ciriaco Miguel Vigil, 9, 33006 Oviedo - Asturias, Spain

Received: 17 July, 2021

Accepted: 27 August, 2021

Published: 28 August, 2021

*Corresponding author: Marta M Pisano-González, Ministry of Health of the Principality of Asturias (CSPA), C/ Ciriaco Miguel Vigil, 9, 33006 Oviedo - Asturias, Spain, E-mail:martam.pisanogonzalez@asturias.org ORCID: https://orcid.org/0000-0002-6485-9370

Keywords: Vulnerable groups; Social determinants of health; Intersectoral collaboration; Self-care; Chronic disease; Integrated Care

https://www.peertechzpublications.com

\section{Check for updates}

\footnotetext{
Abstract

Introduction: Vulnerable people with chronic conditions should be a priority of policy and interventions. Very often, however, they are hard-to-reach and reluctant "to come to see us"

This paper describes the intersectoral alliances used in the EU funded project EFFICHRONIC to identify and enrol hard-to-reach vulnerable populations with chronic conditions to participate in a self-care programme.
} 
Methods: The recruitment approach combined population-based and individual strategies. Vulnerability maps based on specific deprivation indices were developed to prioritize the intervention in those areas with higher vulnerability. Within those areas, potential participants were individually recruited following a variety of recruitment strategies.

Results: To reach the vulnerable population, alliances with local and regional authorities, health services, social care organizations and civil society were generated across the EFFICHRONIC sites.

As a result of this collaborative effort, a total number of 2.951 vulnerable participants distributed over the 5 European countries have been engaged.

Discussion: Forging cross-sectoral alliances has been both enriching and challenging. Our key learnings from this experience include: create a persuasive vision; identify the right agents in the territory, the key people in the organisations and the influential leaders within the community; keep continuous liaison and communications, and ensure effective leadership.

Conclusion: Our learnings can contribute to future improvements for policy and practice.

\section{Introduction}

Over the last decades, both the literatures on chronic care [1] and integrated care [2] have gradually been recognizing the importance of the social determinants in shaping people's health. In their continuous intertwining, both fields coincide in acknowledging that healthcare strategies and interventions should not only consider individual factors, but also people's environment (including socio-economic determinants).

Several studies have demonstrated that individuals at risk of exclusion develop greater morbidity and mortality, in particular for the most prevalent chronic diseases such as cardiovascular diseases, respiratory illnesses, diabetes mellitus and cancer [3]. Applying the reasoning of the Inverse Care Law described by Tudor Hart [4], it is precisely the most vulnerable people with chronic conditions who most need social and community support as well as effective and integrated care to the maximum. However, they generally happen to suffer most from the fragmentation of care services.

Consequently, integrated healthcare strategies should prioritize vulnerable people with chronic conditions and this kind of commitment appears very often in specialized literature [5] or international and national policy documents[6]. However, there is less awareness of the fact that individuals from vulnerable groups are usually hard-to-reach [7,8], and often, they are reluctant to attend the care system and do not seek support through the usual channels [9]. The EU-funded project VulnerABLE [10]. found that even in developed health systems with universal health coverage, some groups are still out of reach. Thus, while the discourse and policy intentions develop (Integrated Care foundation [11], the challenge lies at the policy and practice level.

The question therefore is: how can we actually reach out to vulnerable people with chronic conditions who "do not come to see us"? Taking on this practical challenge, the EUfunded project EFFICHRONIC [12] was developed, a three-year project aiming to recruit hard-to-reach vulnerable people with chronic conditions and caregivers to involve them in a chronic disease self-management programme that helps them to handle several aspects of their health. The targeted population had both to suffer from one or more chronic conditions and fall within our definition of vulnerability.

In the project, five European pilot sites implemented the evidence-based educational CDSMP and the initial objective was to involve at least 2,000 people from vulnerable populations with chronic conditions and caregivers. The implicated European areas were the region of Occitanie in France, the province of Genoa in Italy, the region of Rotterdam in the Netherlands, the principality of Asturias in Spain and several areas in the United Kingdom [13]. EFFICHRONIC specifically shows that reaching out to vulnerable populations requires stepping beyond the formal boundaries of conventional roles and services, and such venture entails intersectoral alliances among a wide range of actors, all working together towards the same goal. This paper aims to describe these intersectoral strategies and collaborative approaches used in EFFICHRONIC to identify, engage with and enrol people with chronic conditions and caregivers from hardto-reach vulnerable populations, to participate in the CDSMP intervention. We are hopeful that the learnings will contribute to future improvements for policy and practice.

\section{Theory and methods}

This section explains the conceptual groundings and the methodology for the recruitment of vulnerable population as well as our learning process during the EFFICHRONIC project.

\section{Conceptual groundings}

EFFICHRONIC results from the dialogue of various conceptual groundings, such as the recent convergence of literatures on chronic care and integrated care in recognizing the importance of the social determinants in shaping people's health. The 2011 World Conference on Social Determinants of Health defined these as "those societal conditions in which people are born, grow, live, work and age [14]. Thus, "the notion of integrated care has gone beyond the borders of the health and social care systems to think more strategically about how to embrace the social determinants of ill-health through bringing together the wider range of community assets to promote public health, prevent ill-health, and secure wellbeing to populations" [15]. People's health and wellbeing depend as much on individual characteristics (age, sex and hereditary factor) and lifestyles as on the social, economic, political, environmental and cultural conditions in which they live. Therefore, people's ability to manage their chronic conditions is consequently shaped by both individual and societal parameters.

Social determinants expose people to multiple situations of vulnerability, a concept widely used in the health literature 
although very rarely defined. The World Health Organization and the International Federation of Red Cross and Red Crescent Societies described vulnerability as the diminished capacity of an individual or group to anticipate, cope with, resist and recover from the impact of a natural or manmade hazard (WHO, 2019) [16]. A common use of the term vulnerability refers to people in poverty or marginalized: vulnerable people would equate to "poor", "marginalised", "deprived" or "disadvantaged" and would typically include homeless people, asylum seekers or people from ethnic minority communities. However, vulnerability can equally appear even if the individual has his/her basic needs (e.g: food, housing) covered but the individual lacks instead family or social ties. "Vulnerability is most often associated with poverty, but it can also arise when people are isolated, insecure and defenseless in the face of risk, shock or stress" [16].

In EFFICHRONIC, vulnerability is used as an umbrella concept to include not only people suffering from socioeconomic hardship but also citizens who are under physical or psychological stress. Not only poverty but also the lack of family ties or social relationships can make people end up in a disadvantaged position [17] As such, the vulnerability concept in the EFFICHRONIC project is approached from both its individual and social dimension.

EFFICHRONIC focuses mainly on vulnerable people who do not seek support through the usual avenues, are hard-toreach for the health services and therefore, have traditionally been underserved $[7,8]$. Literature data suggest several reasons why they may fall through the care net or, in other words, are being let down by the system: they fail to attend voluntarily, are stigmatized, or encounter barriers created by the system itself [18]. A good but rare example of reaching out beyond the hospital walls and the traditional limitations of hospital medicine is the Montefiore Health System in New York, in their labor of supporting a struggling population. As Montefiore's doctors and nurses explain: if you wish to support the most deprived people in your population, you must go out and find them [19].

It is also possible that reaching vulnerable people is more difficult because many of them do not associate with other members of their group, as they are often defined by individual attributes (such as income or health status) and there is no reason for within-population socializing. Also, many population members do not have strong social links and might even resist such contact. Reaching out to non-associative individuals entails different recruitment strategies than the ones used for identifiable vulnerable groups, for instance, Roma people, travelers or asylum seekers [20]. Elderly people living in deprived areas, for example, are more hesitant to participate in health promotion activities due to apathy and little social interaction. Then again, low literacy, lack of formal education, transient and precarious lives, the anticipation of discrimination and rejection are challenges to overcome when engaging hard-to-reach groups from ethnic minorities.

A similarly firm conceptual grounding links EFFICHRONIC to the long-standing literature on the importance of promoting better health literacy and self-care, in particular for the selfmanagement of chronic diseases, as a means to facilitate people to change their personal lifestyles and living conditions [21]. However, social determinants of health shape the capacity of people - in particular vulnerable people- to self-manage their own chronic conditions.

Among the existing chronic disease programs, Stanford's Chronic Disease Self-Management Programme (CDSMP) stands out for its method [22], wide coverage and evidencebased validation [23]. The CDSMP aims to train people in self-efficacy by teaching them skills to manage their chronic conditions. It takes place in a small group (12-20 participants) workshop, of one session per week for six consecutive weeks, facilitated by two non-professional peers (with one or more chronic conditions themselves) [24]. The underlying conceptual elements in the CDSMP are self-efficacy, empowerment, peerto-peer education, salutogenesis and community participation. The most important topics covered during the weekly sessions are: making weekly action plans, problem-solving, decisionmaking, relaxation, cognitive symptom management, painful emotions, fitness/exercise, better breathing, healthy diet, communication, medications, depression, and working with health care professionals. Most importantly, the programme motivates people to take control of their life and self-manage their disease [25].

\section{Methodology for the EFFICHRONIC recruitment}

The challenge of promoting self-care among vulnerable populations with chronic conditions truly lies at the policy and practice level. How to approach individuals from vulnerable groups who may be hard-to-reach, and even reluctant to seek support through the usual channels? In this section, we describe the methodology used in the EFFICHRONIC project to recruit participants.

\section{Definition of the target population}

The first step was to agree on the specific vulnerable target groups, which were defined in detail by the entire EFFICHRONIC consortium, and the sample inclusion criteria was developed to ensure a rigorous quality during intervention. These include persons older than 18 years with chronic disease and vulnerability conditions such as inmates, ethnic minorities, people on a low income, immigrants and elderly people (older than 65 years of age) living alone as well as isolated caregivers [24].

The CDSMP methodology requires certain basic levels of intellectual capacity, mobility, and ability to make personal choices and certain stability in one's life project without which it becomes extremely difficult to fully participate and benefit from the programme. These requirements have then been the exclusion criteria for recruiting people. For example people sleeping on the street every nigh might find very hard to engage with the basics of the CDSMP, including regularly attending weekly workshops. 


\section{Combining population and individual parameters to re- cruit participants}

The recruitment process was carried out simultaneously at all European study sites, adapting it to the socio-economic context, the health system and cultural singularities of each country. Reflecting our conviction that people's ability to manage their chronic conditions is consequently shaped by both societal and individual parameters, the development of EFFICHRONIC's recruitment approach combined populationbased and individual recruitment strategies.

First, vulnerability maps were developed to detect areas with higher vulnerability, to prioritize the intervention there. The areas were identified using specific deprivation indices, employing different methodologies. The maps are based on Population Census data in Spain (the MEDEA index [26] and an ad hoc rural index), France (the FDep index [27] and Italy (the Crevari and Caranci indices (Caranci, et al. 2010) In the United Kingdom, the national Index of Multiple Deprivation [28] (IMD) produces an overall relative measure of deprivation and was consulted online. In the Netherlands, most vulnerable areas at this study site were identified by stakeholders working in the community.

Following, within those identified vulnerable areas, potential participants were individually recruited following a variety of recruitment strategies. While the CDSMP Administrative/Implementation Manual suggests different strategies to advertise the workshops and recruit participants (Self-Management Resource Centre [SMRC], 2019)], hardto-reach individuals imply challenges that are not directly addressed by the Manual and new strategies had to be developed. The starting point was the holding of a workshop in each country with selected experts and stakeholders from the local community that are involved in the health and social care of vulnerable people or people with chronic conditions to discuss jointly the most appropriate techniques to recruit hard-to-reach populations.

\section{Forging intersectoral alliances has been instrumental}

The quest for integrated care has often been depicted as crossing the boundaries [29], going beyond silos [30] or cutting across multiple systems, services, providers and settings. Indeed, that is exactly what hard-to-reach vulnerable populations require from us and this has been one of the most enriching (and challenging) experiences of the whole EFFICHRONIC team: the forging of cross-sectoral networks of stakeholders and representatives of vulnerable groups. All project partners had to step out of the comfort zone of their usual work environment to achieve such collaborations. The following of the paper describes our intersectoral efforts.

\section{Research paper}

The research presented in the Discussion section of this paper results from a laborious retrospective exercise of what we have experienced and learned through the EFFICHRONIC fascinating journey. This retrospective and reflective exercise was done by obtaining information from different sources, including project deliverables, monthly reports and meeting minutes as well as interviews conducted with project partners and stakeholders. The initial results were brought back to the project partners for its internal discussion.

\section{Results}

A total number of 2,951 participants distributed over the five countries have been successfully engaged in a CDSMP workshop over the whole project implementation time. Given that the original project goal was 2000 people, we are therefore proud to report a significantly higher number of participants than originally expected.

All sites targeted people with low-income but also immigrants, isolated caregivers, older persons living alone or in institutions, Roma communities and prisoners. In Italy, there was a stronger emphasis on seniors. In France, Spain and Italy, rural communities were reached. In Asturias, recruitment of institutionalized people, such as in the central prison and therapeutic communities, have been of special interest. In France, trained leaders also performed a very active recruiting job.

This achievement has truly been the result of a broad collective effort. To reach the vulnerable target population for EFFICHRONIC, alliances and collaborations with local and regional authorities, health services, social care organizations and civil society representatives were generated across the EFFICHRONIC sites. The context-specific characteristics in each territory adjusted the specific strategies used.

\section{Institutional alliances}

Alliances with different types of regional, municipal and lower-level authorities were created in all involved areas (Table 1). In Asturias for example, a direct link was established between the Public Health Department and the Regional Ministry of Social Services. In the French Occitanic region, the Regional Health Authority was contacted to establish a network in the semi-rural areas, while the Public Health Authority in Wales was likewise involved to identify local programme providers working with vulnerable people.

At the local level, the EFFICHRONIC partners actively sought support from city councils contacting mayors and councilors. The objective of creating these alliances was threefold: to announce the project at the municipalities, to mobilize resources for participant transport and caregivers

Table 1: Institutional alliances in EFFICHRONIC.

\begin{tabular}{|c|c|l|}
\hline Country & & \multicolumn{1}{c|}{ Stakeholder } \\
\hline & - & Regional Ministry of Health (CSPA) \\
\hline Asturias - Spain & - & Regional Ministry of Social Services \\
& - & The Regional Prison of Asturias \\
\hline Montpellier-France & - & Various Board of Mayors of Asturias \\
\hline United Kingdom & - & Public Health Wales \\
\hline Rotterdam - The Netherlands & - & Municipality of Rotterdam \\
\hline Genoa - Italy & - Municipality of Utrecht \\
\hline & & Municipality of Genoa \\
\hline
\end{tabular}

Citation: Rosete AA, Pisano-González MM, Boone ALD, Alvarez RV, Maestre DP, et al. (2021) Crossing intersectoral boundaries to reach out to vulnerable populations with chronic conditions in five European regions. Arch Community Med Public Health 7(2): 182-190. DOI: https://dx.doi.org/10.17352/2455-5479.000159 
replacement and to help the city council staff with the different organizational aspects of the programme. As an example, the Italian EFFICHRONIC team engaged with the municipality of Genoa and several city council employees assisted in the programme to increase their knowledge on the intervention. In Rotterdam, the municipality was involved from the start and identified and contacted interesting stakeholders. Also, in a remote rural area of Asturias, the coalition of mayors of different villages facilitated the recruitment of participants in what is a very disperse territory Table 1.

\section{Collaborations with health organizations}

The involvement in the project of the different national health systems is a logical measure not only because four of the five partners belong to a health care institution, but also because subgroups of the target population are in regular contact with many types of health workers who may have an important influence on patients. The Dutch, Italian and French EFFICHRONIC study sites are based at a university or regional hospital, and much of their recruitment efforts focus on sensitizing in-house health care professionals.

An innovative move for recruitment in the project was the involvement of General Councils of health-related professionals, such as doctors or pharmacists. By establishing alliances with these organizations (such as the General Medical Council in France, the National Hospital Association in Italy or the Asturian regional Council of community pharmacists), recruitment was organized through their affiliates.

The collaboration with retail pharmacists was extremely interesting, as they could provide their retail network that reaches the most remote and isolated areas.

In places where health and social care coordination teams exist, alliances with them were actively established. For example, in Asturias, Health and Social Care Coordination Teams aim to improve coordinative actions between both sectors and organize integrated care activities. The structures are either regulated by law or less formal, such as the Health Councils or Municipal Health Schools. Working with them was key to success in the strategic planning of citizen participation projects as they have a high impact in the territory. Table 2 resumes the alliances with healthcare organizations in all participating countries.

\section{Involving social sector organizations}

The creation of coalitions with community-based social care organizations turned out to be a particularly important strategy in the project (Table 3). Social workers often work with the most deprived of society, who are usually unreachable for other services. These professionals are generally well-known by their users and in their community working environment. As such, they had the perfect profile to coordinate the intervention in the territory because of their strategic vision, their expert know-how and reference role. The involvement of social workers- worked very well in rural settings in France.

A special effort was made to connect with organizations that allow participant recruitment at residential care homes,
Table 2: Health organizations participating in EFFICHRONIC.

\begin{tabular}{|c|c|}
\hline Country & Stakeholder \\
\hline Asturias - Spain & $\begin{array}{l}\text { - Health Service of the Principality of Asturias } \\
\text { (SESPA) } \\
\text { - Central University Hospital of Asturias \& all local } \\
\text { hospitals } \\
\text { - Community Health Centers of all areas } \\
\text { - } \quad \text { General Council of Retail Pharmacists } \\
\text { Leangreo, Avilés and Gijón }\end{array}$ \\
\hline Montpellier-France & $\begin{array}{l}\text { - Different departments within the CHUM hospital } \\
\text { - } \quad \text { Gentre Hospitalier Clermont-I'Herault } \\
\text { - } \quad \text { and departments } \\
\text { - } \quad \text { Regional Association of private practitioners } \\
\text { - Cenmission of Pays Coeur d'Hérault } \\
\text { - MAIA network for integrated care }\end{array}$ \\
\hline United Kingdom & $\begin{array}{l}\text { - National Health Service England } \\
\text { Talking Therapies (NHS organization in East } \\
\text { London) }\end{array}$ \\
\hline $\begin{array}{c}\text { Rotterdam - The } \\
\text { Netherlands }\end{array}$ & $\begin{array}{l}\text { Different departments within the collaborating } \\
\text { hospital EMC } \\
\text { - Health center Zonboog }\end{array}$ \\
\hline Genoa - Italy & $\begin{array}{ll}\text { - } & \text { National Health Service (ASL) } \\
\text { - } & \text { Different departments within the collaborating } \\
\text { hospital EOG } \\
\text { - } \quad \text { General Council of Medical Doctors, Nurses and } \\
\text { Psychologists } \\
\text { - National Hospital Association }\end{array}$ \\
\hline
\end{tabular}

Table 3: Implied social work entities and related services in EFFICHRONIC.

\begin{tabular}{|c|c|}
\hline Country & Stakeholder \\
\hline $\begin{array}{l}\text { Asturias - } \\
\text { Spain }\end{array}$ & $\begin{array}{l}\text { - } \quad \text { Local social services over the territory } \\
\text { - Social workers from healthcare institutions } \\
\text { - Social and Day centers for the elderly (Pola de Laviana, } \\
\text { - } \quad \text { Nurón, La Felguera) } \\
\text { - Therapeutic community "La Santina" }\end{array}$ \\
\hline $\begin{array}{l}\text { Montpellier- } \\
\text { France }\end{array}$ & $\begin{array}{l}\text { - } \quad \text { Social workers at the CHUM } \\
\text { - } \quad \text { Social workers at the municipal centres for social action }\end{array}$ \\
\hline $\begin{array}{l}\text { United } \\
\text { Kingdom }\end{array}$ & $\begin{array}{ll}\text { - } & \text { BME United Birmingham } \\
\text { - } & \text { Citizens Advice South Derbyshire }\end{array}$ \\
\hline Genoa - Italy & - General Council of Social Workers \\
\hline
\end{tabular}

*The Netherlands did not establish alliances with social sector organizations

where people suffer important isolation and deprivation. In Italy for instance, recruitment was sought at the residential long-term care facility linked to the partners' geriatric hospital. In France, CDSMP workshops were held in a regional Rehabilitation Care facility. In Asturias, active collaborations were established with the regional prison, several nursing homes and also, therapeutic communities.

\section{Engagement with civil society groups}

Many different groups of citizens, such as neighbors, patients sharing the same condition, elderly people or women or ethnic minorities such as Roma people, participate actively in associations with which the EFFICHRONIC partners sought alliances to recruit among their members. These organizations usually offer very specific resources and are highly appreciated by their associates, ensuring high fidelity with the CDSMP. 
It needs to be underlined that, when working with culturally different and inaccessible populations, (i.e. ethnic minorities) the involvement of sociocultural mediators is fundamental to assure effective recruitment.

Examples of implicated patient associations are organizations for spinal injuries, visual impairment or hearing loss in Spain, the National Association for patients with muscle and neuromuscular genetic disorders in France or a patient association with a large regional network in the Netherlands.

Additionally, collaborations with local-regional organizations with strong cultural, industrial or historical roots were established, as is the case of the coal miners associations in Asturias. In this region, the mining activity was the main source of income during the last century and many citizens have a strong feeling of belonging to this association, favouring recruitment among its members.

Finally, organized volunteer networks are of enormous support as they often provide services to the most disadvantaged of society and they exist in all countries. Their special sensitivity to issues of marginalization and proximity to vulnerable people transform them into valuable allies for the project. Table 4 represents the information on collaborating entities from civil society.

All partners organized recruitment through selected NonGovernmental Organizations (NGOs) working with vulnerable

Table 4: Alliances with civil society groups in EFFICHRONIC.

\begin{tabular}{|c|c|}
\hline Country & Stakeholder \\
\hline Asturias - Spain & $\begin{array}{l}\text { - } \text { Mineworkers trade union Montepio } \\
\text { - } \text { Associations of Roma people: UNGA, Secretariado } \\
\text { - } \text { - NGOs: Red Cross, Cáritas, ACCEM, ONCE } \\
\text { - } \quad \text { Helpline "El teléfono de la Esperanza" } \\
\text { - } \quad \text { Neighbourhood associations in several cities } \\
\text { - } \quad \text { Association of people with mental health problems } \\
\text { - } \quad \text { and their families AFESA } \\
\text { - } \quad \text { Federation of hearing impaired of Asturias } \\
\text { FESOPRAS }\end{array}$ \\
\hline Montpellier-France & $\begin{array}{ll}\text { - } & \text { NGOs: ATD Quart monde, Restos du Coeur } \\
\text { - } & \text { Trade Union Sydel du Pays Coeur d'Hérault } \\
\text { - } & \text { Patient association AFM-Téléthon } \\
\text { - } & \text { Patient association AFPRic } \\
\text { - } & \text { Patient association Diabète Recherche Éducation } \\
& \text { Alimentation Métabolisme (DREAM) }\end{array}$ \\
\hline United Kingdom & $\begin{array}{ll}\text { - } & \text { Talking Health, Taking Action (THTA) } \\
\text { - } & \text { Volunteer networks of collaborating stakeholders } \\
\text { - } & \text { Action Heart West Midlands }\end{array}$ \\
\hline $\begin{array}{l}\text { Rotterdam - The } \\
\text { Netherlands }\end{array}$ & $\begin{array}{ll}\text { - } & \text { Patient association Zorgbelang Brabant } \\
\text { - } & \text { Healthy Society Rotterdam } \\
\text { - } & \text { Volunteer Associations UVV } \\
\text { - } & \text { Volunteer organization VMO Radar } \\
\text { - } & \text { Humanitas Foundation }\end{array}$ \\
\hline Genoa - Italy & $\begin{array}{ll}\text { - } & \text { Liguria Alzheimer Association } \\
\text { - } & \text { Hospital Volunteer Association AVO } \\
\text { - } & \text { Several trade unions: CGIL-SPI, UILP, CISL-FNP } \\
\text { - } & \text { CELIVO association } \\
\text { - } & \text { Regional Education Institute }\end{array}$ \\
\hline
\end{tabular}

people. These organizations usually have a wide network of volunteers and professionals who have a big impact on the target population. Some of the collaborating NGO's eventually became members of the project External Advisory Boards in each country due to their important counselling role. The NGOs, acting as intermediaries, contacted and recruited participants among immigrants, refugees, ethnic minorities and people having difficulties to make ends meet.

In the UK, the project benefits from a large existing network of CDSMP-licensed organizations, and of special interest were the ones working with vulnerable populations. In some areas, the National Health System is involved while in others, NGO's or patient associations organized the programme. The type and focus of these organizations depend mostly on the loco-regional circumstances and the kind of target population they serve, such as ethnic minorities or economically deprived groups.

Finally, also informal networks such as groups of neighbors, friends or family, and word-to-mouth publicity are rich sources for recruitment.

\section{Discussion}

Forging these cross-sectoral alliances with local and regional authorities, health services, social care organizations and civil society representatives of vulnerable groups has been both enriching and challenging. While a detailed description of our experiential journey goes beyond the word limits of this paper, we can however share our key learning.

1. It has been essential the building up of a persuasive narrative or vision to share with potential collaborators which entailed the following characteristics:

a. An appealing message: "the care systems are not reaching out to vulnerable people with chronic conditions who might be most needing a targeted support". This message provided the sufficient appeal, legitimacy and impulse for stakeholders to get on board.

b. An existing and real problem, as shown by research: i.e. in Western societies, the incidence of psychiatric disorders is 7 times higher among the imprisoned population than in the general population [31,32]; the Roma community are exposed to more risk factors, such as the number of alcohol consumption, drugs, tobacco and child obesity [33,34].

c. A feasible solution: the CDSMP. It was not seen as costly, complex nor unsustainable intervention, but rather a methodologically-sound, evidence-based, worldwidetested and cost-effective program.

It has been essential to undertake a project communication and dissemination campaign using a wide range of media channels and social networks.

2. The strategy of prioritizing areas with higher vulnerability has been extremely positive. Very often 
these are territories left out from policy innovations and experiences due to their socio-economic complexity. However, we have found managers and community leaders (in particular in rural areas) with a great disposition to collaborate.

3. In the territories, ensuring collaborations with stakeholders is indeed essential but equally tough. It requires active mapping and identification as well as careful judgement of whom to be involved and how. There is a need to consider the purpose and nature of each organization and balance the potential benefits and risks of their involvement. It needs considering how many stakeholders we will be realistically able to adequately support throughout the project.

4. It is necessary to identify the right person who can move the project forward in each ally organisation and this depends on the size and structure of the organisation:

a. In big organisations, getting the support of the general manager is a necessary but not sufficient condition. Intermediate managers and street-level workers need to be on board as well.

b. In small organisations, getting the full support and continuous involvement of the person at the top is essential.

It is good practice to run the programme first with members of the organisation that will be our allies, because they become the best advocators of the project.

5. There are many agents in the territory truly willing to engage and collaborate:

a. Community health workers, lay workers or peer supporters, are recognized assets to engage hard-toreach groups in health interventions, in addition to the health workforce [34].

b. Retail pharmacists have proved to be a key ally in any public health promotion interventions, given their regular contact with many vulnerable people.

c. Involving caregivers in the project has a positive influence on recruitment [35-41].

However, actors whom one would have considered naturally inclined to support the proposed self-care interventions (namely health care professionals) demonstrated higher resistance to coordinate with others.

6. It is useful to get on board the influential leaders within the community: charismatic members, respected neighbours and ethnic minorities leaders. In particular, when working with culturally different and hard-toreach populations, the involvement of sociocultural mediators is really useful to assure effective recruitment.

7. Constant nurturing of the collaborations is equally essential. The project requires continuous liaising and communicating to keep everyone aligned, engaged and fully supportive.

8. The CDSMP method has proved useful for working with vulnerable populations, and we confirm that the methodology works well. However, we have had to make some adjustments to meet particular needs and characteristics of the end-users: i.e. limit the time of the sessions; adapt to people's timetables and habits; overcome language barriers with translators; align session and public transport timetables, in particular in rural areas.

9. All the points above converge towards a common note: they all reflect how fundamental the effective leadership in each site is. This has been extremely timeconsuming and we were not fully aware of the scope of such task at the very start of the project. In addition, intense coordination between all sites was required throughout the project duration.

10. Finally, it is important to consider the role of the country-specific contexts that can strongly determine its implementation pace and path. These contextual elements can be system-wide (i.e. specific configurations of the care systems) or transient factors (i.e. current country debates on chronic care, self-management and integrated care) or regulatory elements (i.e. administrative requirements such as getting ethics committee approval).

\section{Conclusions}

How can we reach out to vulnerable people with chronic conditions "who do not come to us"? This article has argued that developing recruitment strategies through intersectoral collaborations is the most effective way of reaching the highest number of participants from vulnerable populations. To reach the target population, all partners had to leave their comfort zone to create alliances with organizations and population groups they usually do not work with. Doing this, they succeed in connecting to the most needed of society and handing them the tools to improve their self-management. The main conclusion of this paper is that a great variety of key agents from different sectors in the territories must be engaged in the recruitment process. It is fundamental that the various strategies are implemented simultaneously and that the process is coordinated by an effective project management team to optimize the results.

\section{Acknowledgements}

This manuscript is part of the project / joint action ' 738127 / EFFICHRONIC' "Enhancing health systems sustainability by providing cost-efficiency data of evidenced based Interventions for chronic management in stratified population based on clinical socio-economic determinants of health" which has received funding from the European Union's Health Programme (2014-2020).

Trial registration: ISRCTN registry number is 70517103 . Date of registration is $20 / 06 / 2018$. 
The members of the EFFICHRONIC Consortium are: Marta M Pisano Gonzalez, Raquel Vazquez Alvarez, Delia Peñacoba Maestre (Health Service of the Principality of Asturias - SESPA, Spain); An LD Boone, José Ramón Hevia Fernandez y Sergio Valles Garcia (Regional Ministry of Health - Government of the Principality of Asturias - CSPA, Spain); Inés Rey and Raquel Ochoa Gonzalez (the Foundation for the Promotion in Asturias of applied Scientific Research and Technology - FICYT, Spain); Yves-Marie Pers, Christian Jorgensen, Verushka Valsecchi, Rosanna Ferreira Lopez, Adrien Durand, Cristina Balaguer Fernandez, Dallal Fracso (The University Hospital Center of Montpellier - CHUM, France); Graham Baker, Danni Brown and Suzanne Lucas (Qismet, Portsmouth, UK); Siok-Swan Tan, Irene Fierloos, Xuxi Zhang, Petra de Vries, Hein Raat (Erasmus MC University Medical Center, Rotterdam, The Netherlands); Alberto Pilotto, Sabrina Zora, Alberto Ferri, Alberto Cella and Alessandra Argusti (EO Galliera Hospital, Genoa, Italy); Ascensión Doñate Martínez, Laura Llop Medina and Jorge Garcés (University of Valencia, Polibienestar Research Institute - UVEG, Valencia, Spain). Arturo Álvarez Rosete is the EFFICHRONIC external consultant for WP 7.

\section{References}

1. Dalstra JA, Kunst AE, Borrell C, Breeze E, Cambois E, et al. (2005) Socioeconomic differences in the prevalence of common chronic diseases: an overview of eight European countries. Int J Epidemiol 34: 316-326. Link: https://bit.ly/3ymw9px

2. Kodner DL, Spreeuwenberg C (2002) Integrated care: meaning, logic applications, and implications-a discussion paper. Int J Integr Care Int J Integr Care 2: e12. Link: https://bit.ly/2WthGej

3. Marmot M, Wilkinson R (Eds.) (2005) Social determinants of health. Oup Oxford 365. Link: https://bit.ly/2WrpYE2

4. Hart JT (1971) The inverse care law. Lancet 297: 405-412. Link: https://bit.ly/3zpLSWp

5. Hébert R (2017) Canada: application of a coordinated-type integration model for vulnerable older people in Quebec: the PRISMA project. In Handbook Integrated Care. Springer, Cham 499-510. Link: https://bit.ly/3mG25TS

6. Goyer CF (2011) Key Elements of Integrated Care for Persons Experiencing Homelessness. Link: https://bit.ly/3BjTGcS

7. Bonevski B, Randell M, Paul C, Chapman K, Twyman L, et al. (2014) Reaching the hard-to-reach: a systematic review of strategies for improving health and medical research with socially disadvantaged groups. BMC Med Res Methodol 14: 1-29. Link: https://bit.ly/3jqu4VD

8. Thompson S, Phillips D (2007) Reaching and engaging hard-to-reach populations with a high proportion of nonassociative members. Qual Health Res 17: 1292-1303. Link: https://bit.ly/3zoCySD

9. Flanagan SM, Hancock B (2010) Reaching the hard to reach'-lessons learned from the VCS (voluntary and community Sector). A qualitative study. BMC Health Serv Res 10: 92. Link: https://bit.ly/3ztovev

10. Costongs C (2017) Euro Health Net. Impact 96-97. Link: https://bit.ly/3DqzWG3

11. Liljas AE, Walters K, Jovicic A, lliffe S, Manthorpe J, et al. (2019) Engaging 'hard to reach'groups in health promotion: the views of older people and professionals from a qualitative study in England. BMC Public Health 19: 629. Link: https://bit.ly/3ysbPDg

12. European Union's Health Programme, EFFICHRONIC Project. Ficyt, Asturias.
Link: http://effichronic.eu/

13. Boone AL, Pisano-Gonzalez MM, Valsecchi V, Tan SS, Pers YM, et al. (2019) EFFICHRONIC study protocol: a non-controlled, multicentre European prospective study to measure the efficiency of a chronic disease selfmanagement programme in socioeconomically vulnerable populations. BM Open 9: e032073. Link: https://bit.ly/3krijgO

14. World Health Organization (2011) Rio political declaration on social determinants of health. In World conference on social determinants of health. Rio de Janeiro: World Health Organization 21. Link: https://bit.ly/3sVh5yf

15. Goodwin N, Stein V, Amelung V (2021) What is integrated care?. In Handbook integrated care. Springer, Cham 3-25.. Link: https://bit.ly/2WoCmEN

16. International Federation of Red Cross and Red Crescent Societies (IFRC) What is vulnerability?. Link: https://bit.ly/3gYBQ7B

17. Española CR (2007) Informe anual sobre la vulnerabilidad social 2006. Madrid Cruz Roja Espanola.

18. Hoppitt T, Shah S, Bradburn P, Gill P, Calvert M, et al. (2012) Reaching the 'hard to reach': strategies to recruit black and minority ethnic service users with rare long-term neurological conditions. International Journal of Social Research Methodology 15: 485-495. Link: https://bit.ly/3t1Fi68

19. Collins B (2018) The Montefiore Health System in New York. London: The Kings Fund. Link: https://bit.ly/3mN3B6q

20. Horowitz CR, Brenner BL, Lachapelle S, Amara DA, Arniella G (2009) Effective recruitment of minority populations through community-led strategies. Am J Prev Med 37: S195-S200. Link: https://bit.ly/3gBnZ6M

21. Lorig KR, Sobel DS, Ritter PL, Laurent D, Hobbs M (2001) Effect of a selfmanagement program on patients with chronic disease. Eff Clin Pract ECP 4 256-262. Link: https://bit.ly/3jnWNuf

22. Lorig KR, Sobel DS, Stewart AL, Brown BW, Bandura A, et al. (1999) Evidence suggesting that a chronic disease self-management program can improve health status while reducing hospitalization: a randomized trial. Med Care 37 5-14. Link: https://bit.ly/3kwSJXN

23. Ory MG, Smith ML, Ahn S, Jiang L, Lorig K, et al. (2014) National study of chronic disease self-management: age comparison of outcome findings. Health Educ Behav 41: 34S-42S. Link: https://bit.ly/3DnFEZn

24. Tan SS, Pisano MM, Boone AL, Baker G, Pers YM, et al. (2019) Evaluation design of EFFICHRONIC: the chronic disease self-management programme (CDSMP) intervention for citizens with a low socioeconomic position. International Journal of Environmental Research and Public Health 16: 1883. Link: https://bit.ly/3jnh82E

25. Richardson G, Kennedy A, Reeves D, Bower P, Lee V, et al. (2008) Cos effectiveness of the Expert Patients Programme (EPP) for patients with chronic conditions. J Epidemiol Community Healt 62: 361-367. Link: https://bit.ly/3Bilka3

26. Esnaola S, Montoya I, Calvo M, Ibáñez B, Audicana C, et al. (2009) Desigualdades socioeconómicas en la mortalidad en el País Vasco y sus capitales: un análisis de áreas geográficas pequeñas (Proyecto MEDEA). Estudios Geográficos 70 443-462. Link: https://bit.ly/2WBuLT8

27. Challier B, Viel JF (2001) Pertinence et validité d'un nouvel indice composite français mesurant la pauvreté au niveau géographique. Revue d'épidémiologie et de santé publique 49: 41-50. Link: https://bit.ly/3gYBFZZ

28. Communities OD (2015) Indices of Deprivation 2015 explorer. Available at Web site http://dclgapps. communities. gov. uk/imd/idmap. Link: https://bit.ly/3gEzavz

29. Timmins N, Ham C (2013) The quest for integrated health and social care: a case study in Canterbury, New Zealand. London: Kings Fund. Link: https://bit.ly/3mF9WAV

Citation: Rosete AA, Pisano-González MM, Boone ALD, Alvarez RV, Maestre DP, et al. (2021) Crossing intersectoral boundaries to reach out to vulnerable populations with chronic conditions in five European regions. Arch Community Med Public Health 7(2): 182-190. DOI: https://dx.doi.org/10.17352/2455-5479.000159 
30. Beyond Silos Project. European project (2014) The EC Information and Communication Technologies Policy Support Programme. Available at Web Site.

31. Arroyo-Cobo JM (2011) Estrategias asistenciales de los problemas de salud mental en el medio penitenciario, el caso español en el contexto europeo. Revista española de sanidad penitenciaria 13: 100-111. Link: https://bit.ly/3jnWD67

32. Hoke S (2015) Mental illness and prisoners: Concerns for communities and healthcare providers. Online J Issues Nurs 20: 3. Link: https://bit.ly/2UTcAaO

33. García VC, Ros EO, Toledo LB, Girona NB, Royo AM, et al. (2000) Cómo son y de qué padecen los gitanos. Atención Primaria 26: 21-25. Link: https://bit.ly/3ktHJdL

34. Ministerio de Sanidad, Servicios Sociales e Igualdad (2014) Segunda Encuesta Nacional de Salud a Población Gitana.

35. Segunda Encuesta Nacional de Salud a Población Gitana 2014. Link: https://bit.ly/3DnFBg9
36. Davies K, Collerton JC, Jagger C, Bond J, Barker SA, et al. (2010) Engaging the oldest old in research: lessons from the Newcastle $85+$ study. BMC Geriatr 10 1-9. Link: https://bit.ly/3DpVHpG

37. Brackertz N (2007) Who is hard to reach and why?. Link: https://bit.ly/3DpxVdf

38. Davis I (2013) Progress in analysis of social vulnerability and capacity. In Mapping vulnerability. Routledge 147-163.

39. González MMP (2018) EFFICHRONIC: un primer paso hacia las personas con mayor vulnerabilidad. RqR Enfermería Comunitaria 6: 4-7. Link: https://bit.ly/2XUXPFy

40. González MP, Boone A, Alvarez-rosete A (2019) Health and Social Care systems reaching out to vulnerable populations with chronic conditions: the EU-project EFFICHRONIC. International Journal of Integrated Care (IJIC) 19

41. Self-Management Resource Centre. Administrative/Implementation manual (2016) Link: https://bit.ly/3Dzj05x
Discover a bigger Impact and Visibility of your article publication with Peertechz Publications

\section{Highlights}

* Signatory publisher of ORCID

- Signatory Publisher of DORA (San Francisco Declaration on Research Assessment)

- Articles archived in worlds' renowned service providers such as Portico, CNKI, AGRIS, TDNet, Base (Bielefeld University Library), CrossRef, Scilit, J-Gate etc.

* Journals indexed in ICMJE, SHERPA/ROMEO, Google Scholar etc.

* OAI-PMH (Open Archives Initiative Protocol for Metadata Harvesting)

* Dedicated Editorial Board for every journa

* Accurate and rapid peer-review process

* Increased citations of published articles through promotions

* Reduced timeline for article publication

Submit your articles and experience a new surge in publication services (https://www.peertechz.com/submission).

Peertechz journals wishes everlasting success in your every endeavours.

Copyright: @ 2021 Rosete AA, et al. This is an open-access article distributed under the terms of the Creative Commons Attribution License, which permits unrestricted use, distribution, and reproduction in any medium, provided the original author and source are credited.

Citation: Rosete AA, Pisano-González MM, Boone ALD, Alvarez RV, Maestre DP, et al. (2021) Crossing intersectoral boundaries to reach out to vulnerable populations with chronic conditions in five European regions. Arch Community Med Public Health 7(2): 182-190. DOI: https://dx.doi.org/10.17352/2455-5479.000159 